\title{
Solid Solutions in the System $\mathrm{Fe}_{1-\mathrm{x}} \mathrm{O}-\mathrm{ZnO}$ at Low Oxygen Partial Pressure
}

\begin{tabular}{|c|c|}
\hline Journal: & Zeitschrift für Anorganische und Allgemeine Chemie \\
\hline Manuscript ID: & zaac. 201000084.R1 \\
\hline Wiley - Manuscript type: & Article \\
\hline $\begin{array}{r}\text { Date Submitted by the } \\
\text { Author: }\end{array}$ & 09-Mar-2010 \\
\hline Complete List of Authors: & $\begin{array}{l}\text { Mader, Werner; University of Bonn, Chemistry } \\
\text { Moll, Sebastian; University of Bonn, Institute of Inorganic } \\
\text { Chemistry } \\
\text { Weber, Sven-Ulf; Technische Universität Braunschweig, Institut für } \\
\text { Physikalische und Theoretische Chemie } \\
\text { Becker, Klaus-Dieter; Technische Universität Braunschweig, Institut } \\
\text { für Physikalische und Theoretische Chemie }\end{array}$ \\
\hline Keywords: & Ferrous oxide, Zinc oxide, Solid solution, Lattice parameters \\
\hline
\end{tabular}

\section{s) ScholaroNE" \\ Manuscript Central}




\title{
Solid Solutions in the System $\mathrm{Fe}_{1-\mathrm{x}} \mathrm{O}-\mathrm{ZnO}$ at Low Oxygen Partial Pressure
}

\author{
Sebastian Moll, ${ }^{[a]}$ Sven-Ulf Weber, ${ }^{[b]}$ Klaus-Dieter Becker, ${ }^{[b]}$ and Werner Mader ${ }^{[a]}$
}

Dedicated to Professor Bernd Harbrecht on the Occasion of His $60^{\text {th }}$ Birthday

Keywords: Ferrous oxide; Zinc oxide; Solid solution; Lattice parameters;

\begin{abstract}
The maximum solubilities of $\mathrm{Zn}^{2+}$ in $\mathrm{Fe}_{1-x} \mathrm{O}$ and of $\mathrm{Fe}^{2+}$ in $\mathrm{ZnO}$ at temperatures from $1173-1473 \mathrm{~K}$ in the presence of metallic iron were determined. Mixed crystals $\mathrm{Fe}_{1-x-z} \mathrm{Zn}_{z} \mathrm{O}$ with $0.04 \leq \mathrm{z} \leq 0.19$ were prepared at $1273 \mathrm{~K}$. All samples were characterised by X-ray diffraction (XRD) and energy dispersive X-ray spectroscopy. The solubility of $\mathrm{Fe}^{2+}$ in wurtzite $\mathrm{ZnO}$ as well as the lattice parameter $a$ of $\mathrm{Zn}_{1-\gamma} \mathrm{Fe}_{y} \mathrm{O}$ increases with reaction temperature whereas $c$ remains virtually constant. The solubility of $\mathrm{Zn}^{2+}$ in $\mathrm{Fe}_{1-\mathrm{x}} \mathrm{O}$ increases with temperature. The lattice parameter $a$ of $\mathrm{Fe}_{1-x-z} \mathrm{Zn}_{z} \mathrm{O}$ for $0.04 \leq \mathrm{z} \leq$ 0.13 increases with $\mathrm{Zn}$ content. For $0.13 \leq \mathrm{z} \leq 0.19 a$ is constant,

whereas for higher $\mathrm{Zn}$ contents $a$ decreases. Mössbauer spectroscopy of the mixed crystal $\mathrm{Fe}_{1-x-0.09} \mathrm{Zn}_{0.09} \mathrm{O}$ yields a reduced amount of $6 \% \mathrm{Fe}^{3+}$ compared to wüstite $\mathrm{Fe}_{1-0.04} \mathrm{O}$ with $9 \% \mathrm{Fe}^{3+}$. Such reduction of $\mathrm{Fe}^{3+}$ content was previously observed in the mixed crystal systems $\mathrm{Fe}_{1-\mathrm{x}} \mathrm{O}-\mathrm{MgO}$ and $\mathrm{Fe}_{1-\mathrm{x}} \mathrm{O}-$ $\mathrm{MnO}$ too. The increase of the lattice parameter $a$ of $\mathrm{Fe}_{1-x-z} \mathrm{Zn}_{z} \mathrm{O}$ for low concentrations is explained by removal of $\mathrm{Fe}^{3+}$ ions. At higher $\mathrm{Zn}$ contents the occupation with $\mathrm{Zn}^{2+}$ ions - with smaller radius than $\mathrm{Fe}^{2+}-$ balances or exceeds the effect of $\mathrm{Fe}^{3+}$ removal.
\end{abstract}

\section{* Prof. Dr. W. Mader \\ Fax: +49-288-734205 \\ E-Mail: mader@uni-bonn.de}

[a] Institut für Anorganische Chemie, Universität Bonn, Römerstrasse 164 53117 Bonn, Germany

[b] Institut für Physikalische und Theoretische Chemie Technische Universität Braunschweig

Hans-Sommer-Str. 10

38106 Braunschweig, Germany

\section{Introduction}

Despite zinc oxide $(\mathrm{ZnO})$ has already many industrial applications owing to its physical and chemical properties, there is renewed interest and wide research activities in the past decade, e.g. on nanometre-sized $\mathrm{ZnO}$ crystals and on the electrical conductivity of the optically transparent oxide. Also, any doping of $\mathrm{ZnO}$ with other metal oxides to eventually implement ferromagnetism to the semiconducting oxide is of high interest [1]. Recently, vast quantity of research is performed on $\mathrm{ZnO}$ systems with small dimensions and as thin films with various additions. In most cases, these systems are produced at low temperature and are thus far from equilibrium. Basic studies on equilibrium systems of $\mathrm{ZnO}$ with other oxides were usually made in the past, and this was the motivation to revisit the system zinc oxide - wüstite. The composition and structure of wüstite is still a matter of research documented in an immense number of studies in the literature.

Ferrous oxide is known as wüstite which crystallises in the rock salt crystal structure. Wüstite is non-stoichiometric, and it is deficient in iron which is represented by the chemical formula $\mathrm{Fe}_{1-x} \mathrm{O}$, with $x$ between 0.04 and 0.15 determined by temperature and oxygen partial pressure [2]. Caused by the non-stoichiometry, part of the iron is high spin $d^{5} \mathrm{Fe}^{3+}$ which occupies tetrahedral as well as octahedral sites. $\mathrm{Fe}^{3+}$ in tetrahedral sites tends to form defect clusters together with vacancies at immediate neighbouring octahedral cation sites [3]. Foster and Welch [4] realised that the lattice parameter $a$ of wüstite depends on its composition, i.e. $a$ increases with increasing $\mathrm{Fe}$ content which is equivalent to the decrease of $\mathrm{Fe}^{3+}$. In recent years, Hayes, Jak, and Pelton [5, 6] studied the phase diagram of the system $\mathrm{Fe}-\mathrm{Zn}-\mathrm{O}$. At low oxygen partial pressures the wüstite type mixed crystal $\mathrm{Fe}_{1-x-z} \mathrm{Zn}_{z} \mathrm{O}$ with zinc solute is in equilibrium with the zinc rich wurtzite type phase $\mathrm{Zn}_{1-y} \mathrm{Fe}_{y} \mathrm{O}$ across the two-phase region. They measured the solid solubility limits in the reaction products of $\mathrm{ZnO}$ which is confined in a metallic iron container [6]. However, the experimental setup did not allow obtaining further results. Claude et al. [7] studied $\mathrm{Fe}_{1-\mathrm{x}} \mathrm{O}$ with varying additions of $\mathrm{ZnO}$ at $1173 \mathrm{~K}$, and they observed an increase of the lattice parameter with zinc content.

In a chemical vapour transport experiment Locmelis et al. [8] obtained zincite crystals containing different amount of Fe. They observed an increase of the lattice parameter $a$ with increasing $\mathrm{Fe}$ content while $c$ remains virtually constant.

In this study we present results of a systematic investigation of the system $\mathrm{Fe}-\mathrm{Zn}-\mathrm{O}$ in the presence of metallic iron, where we determine solubilities, lattice parameters, and in a case study the $\mathrm{Fe}^{3+}$ vs. $\mathrm{Fe}^{2+}$ content in the wüstite type phase.

\section{Experimental Section}

$\mathrm{ZnO}$ (99.999 \% Sigma Aldrich), $\mathrm{Fe}_{2} \mathrm{O}_{3}$ (99.999 \% Acros Organics) and $\mathrm{Fe}$ (99\% Fluka) were mixed in an agate mortar and pressed to pellets. Throughout, $\mathrm{Fe}_{2} \mathrm{O}_{3}$ and $\mathrm{Fe}$ were chosen in molar ratio of 1:1 to obtain wüstite with a small remainder of iron. The pressed mixtures were sealed in fused silica tubes $(40-50 \mathrm{~mm}$ in length, $6 \mathrm{~mm}$ in diameter; filled with $10^{-2} \mathrm{mbar} \mathrm{Ar}$ ) and heated in a tube furnace. The composition of the mixtures and the reaction 
temperatures and times are given in table 1. After reaction the silica tubes were quenched in water.

Table 1. Composition of starting mixtures, reaction parameters and determined compositions of wüstite-type phase.

\begin{tabular}{ccccc}
\hline $\begin{array}{c}\text { Sample } \\
\text { no. }\end{array}$ & $\begin{array}{c}\text { FeO / ZnO } \\
\text { in starting } \\
\text { mixtures }\end{array}$ & $\begin{array}{c}T \\
{[\mathrm{~K}]}\end{array}$ & $\begin{array}{c}\text { Reaction } \\
\text { time } \\
{[\mathrm{h}]}\end{array}$ & $\begin{array}{c}\text { Ratio } \\
\text { Fe / Zn } \\
\text { Wüstite Phase }\end{array}$ \\
\hline 1 & $50 / 50$ & 1173 & 192 & - \\
2 & $50 / 50$ & 1223 & 168 & - \\
3 & $50 / 50$ & 1273 & 168 & - \\
4 & $50 / 50$ & 1323 & 120 & - \\
5 & $50 / 50$ & 1373 & 168 & - \\
6 & $50 / 50$ & 1423 & 168 & - \\
7 & $50 / 50$ & 1473 & 96 & - \\
8 & $95 / 5$ & 1273 & 72 & $96 / 4$ \\
9 & $90 / 10$ & 1273 & 72 & $91 / 9$ \\
10 & $86 / 14$ & 1273 & 72 & $89 / 11$ \\
11 & $85 / 15$ & 1273 & 72 & $88 / 12$ \\
12 & $84 / 16$ & 1273 & 72 & $87 / 13$ \\
13 & $83 / 17$ & 1273 & 72 & $86.5 / 13.5$ \\
14 & $82 / 18$ & 1273 & 72 & $85 / 15$ \\
15 & $81 / 19$ & 1273 & 72 & $84 / 16$ \\
16 & $80 / 20$ & 1273 & 72 & $83 / 17$ \\
17 & $79 / 21$ & 1273 & 72 & $82 / 18$ \\
18 & $78 / 22$ & 1273 & 72 & $81 / 19$
\end{tabular}

Powder X-ray diffraction data were obtained on a digitised Philips PW1050 (Co $\mathrm{K}_{\alpha}$ radiation), Bragg-Brentano geometry, and post specimen monochromator. The powder diffraction diagrams were analyzed with the Diffrakt97 program package [9] which serves as user interface for e.g. the Treor90 [10] program for indexing and for the Rietveld algorithm based on the program LHPM1 [11]. Phase identification was carried out by comparison with the JCPDS-ICSD database cards.

The chemical composition of individual micro-crystals was determined by energy dispersive X-ray spectrometry (EDXS) conducted on a Philips CM30 transmission electron microscope operated at $300 \mathrm{kV}$. Quantitative microanalysis was based on experimentally determined calibration factors derived from standards. Micro-crystals for transmission electron microscopy (TEM) were obtained by grinding the reaction products in an agate mortar. The crystals were dispersed in ethanol and were deposited on a carbon-coated copper grid (Quantifoil R 1.2/1.3, 200 mesh).

Mössbauer measurements were performed in transmission geometry using a microcomputer-controlled spectrometer in constant acceleration mode using a ${ }^{57} \mathrm{Co} / \mathrm{Rh} \gamma$-ray source. The velocity scale was calibrated relative to ${ }^{57} \mathrm{Fe}$ in $\mathrm{Rh}$. The transmitted $\gamma$-radiation was detected by means of a proportional counter. "Recoil" spectral analysis software [12] was used for the quantitative evaluation of the Mössbauer spectra.

\section{Results and Discussion}

\section{Phase Diagram of Zn-Fe-O-System with Metallic Iron}

The Phase diagram of the $\mathrm{Zn}-\mathrm{Fe}-\mathrm{O}$ system in the presence of metallic iron is known to consist of the iron rich wüstite phase with rock salt structure and the zinc rich wurtzite type phase separated by a two-phase field. Thus, in equilibrium an equal amount of $\mathrm{Fe}_{1-\mathrm{x}} \mathrm{O}$ and $\mathrm{ZnO}$ as starting mixture will yield a two phase product with maximum solute content of either $\mathrm{Zn}$ in the wüstite type phase or $\mathrm{Fe}$ in the wurtzite type phase. The presence of these two oxide phases and some small amount of $\alpha$-iron (less than ca. 5 at $\%$ of the iron content) could be verified in all the X-ray powder diffraction (XRD) diagrams collected from samples no. 1 to 7 (see table 1).

Individual single crystals on the supporting carbon film were analysed (i) by electron diffraction to identify the crystal structure and (ii) by EDXS to analyse the ratio of cations, respectively. Only crystals with either $\mathrm{NaCl}$ structure or with wurtzite structure having high iron content or high zinc content, respectively, were observed, and 10 to 20 crystals of any phase and reaction temperature (1173 to $1473 \mathrm{~K}$ ) were analysed. The compositions of the phases at the two-phase field, i.e. the solubility limits, are listed in Table 2 and are visualised in the phase diagram in Figure 1.

Table 2. Solubility limits of $\mathrm{Fe}$ in $\mathrm{Zn}_{1-y} \mathrm{Fe}_{y} \mathrm{O}$ and of $\mathrm{Zn}$ in $\mathrm{Fe}_{1-x-z} \mathrm{Zn}_{z} \mathrm{O}$ as function of temperature.

\begin{tabular}{cccc}
\hline $\begin{array}{c}\text { Sample } \\
\text { no. }\end{array}$ & $\begin{array}{c}T \\
{[\mathrm{~K}]}\end{array}$ & $\begin{array}{c}{[\mathrm{Fe}] /[\mathrm{Fe}+\mathrm{Zn}]} \\
\%\end{array}$ & $\begin{array}{c}{[\mathrm{Zn}] /[\mathrm{Fe}+\mathrm{Zn}]} \\
\%\end{array}$ \\
\hline 1 & 1173 & $16(1)$ & $18(2)$ \\
2 & 1223 & $19(1)$ & $19(1)$ \\
3 & 1273 & $20(1)$ & $20(1)$ \\
4 & 1323 & $22(1)$ & $22(1)$ \\
5 & 1373 & $24(1)$ & $22.5(9)$ \\
6 & 1423 & $25(1)$ & $23(2)$ \\
7 & 1473 & $26(1)$ & $25(1)$ \\
\hline
\end{tabular}

The phase with wurtzite structure, $\mathrm{Zn}_{1-y} \mathrm{Fe}_{y} \mathrm{O}$, as well as the wüstite type phase, $\mathrm{Fe}_{1-x-z} \mathrm{Zn}_{z} \mathrm{O}$, exhibits increasing solute content of $\mathrm{Fe}$ and $\mathrm{Zn}$, respectively, with increasing temperature, attributed to the increase of entropic factors in Gibbs free energy. The solubility limits are consistent with the ones reported by Jak and Hayes [6] despite the different materials preparation and the different methods for chemical analysis. The oxygen partial pressure in the presence of metallic iron varies from $10^{-9}$ to $10^{-13}$ mbar in the reaction temperature range [13].

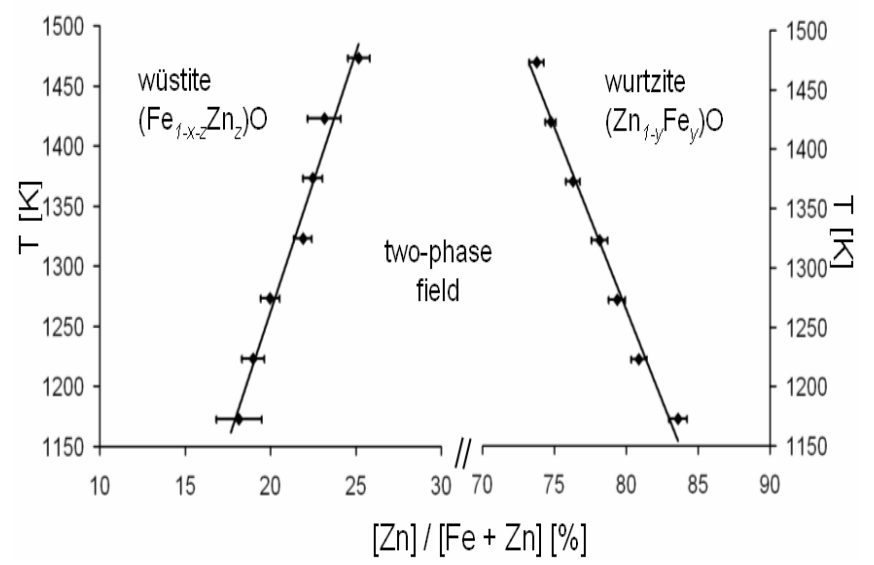

Figure 1. Phase diagram of the system $\mathrm{Zn}-\mathrm{Fe}-\mathrm{O}$ in presence of metallic iron. Error bars of solubility limits represent standard deviations of EDXS measurements.

Wurtzite Type $\mathrm{Zn}_{1-y} \mathrm{Fe}_{y} \mathrm{O}$ 
As result of Rietveld refinements the lattice parameters $a$ and $c$ of the hexagonal phase $\mathrm{Zn}_{1-y} \mathrm{Fe}_{y} \mathrm{O}$ with maximum iron content at the chosen reaction temperatures are given in Table 3. The lattice parameter $a$ increases linearly with increasing $\mathrm{Fe}$ content. However, the lattice parameter $c$ appears to be widely invariant with compositional variations of the samples. As a result the $c / a$ ratios of the mixed crystals vary from 1.589 to 1.594 between highest and lowest $\mathrm{Fe}$ content, respectively. Because the c/a ratio of $\mathrm{ZnO}$ is 1.602 , substitution of $\mathrm{Zn}$ by Fe lowers the $c / a$ ratio of the mixed crystals even more away of the ideal value of 1.633 .

Table 3. Lattice Parameters of hexagonal $\mathrm{Zn}_{1-y} \mathrm{Fe}_{y} \mathrm{O}$ with maximum Fe content (see Table 2).

\begin{tabular}{ccccc}
\hline Sample no. & $a[\AA]$ & $c[\AA]$ & GOF $/ \%$ & $R_{\mathrm{B}} / \%$ \\
\hline 1 & $3.2656(1)$ & $5.2055(1)$ & 7.9 & 3.1 \\
2 & $3.2686(2)$ & $5.2049(3)$ & 12.1 & 1.9 \\
3 & $3.2687(1)$ & $5.2039(2)$ & 9.7 & 5.7 \\
4 & $3.2700(1)$ & $5.2049(1)$ & 8.8 & 6.6 \\
5 & $3.2719(1)$ & $5.2052(1)$ & 8.9 & 1.1 \\
6 & $3.2734(1)$ & $5.2040(2)$ & 12.1 & 9.0 \\
7 & $3.2742(1)$ & $5.2026(2)$ & 8.8 & 2.7
\end{tabular}

The lattice parameters $a$ and $c$ of $\mathrm{Zn}_{1-y} \mathrm{Fe}_{y} \mathrm{O}$ are plotted versus the $\mathrm{Fe}$ content in the wurtzite structure of $\mathrm{ZnO}$ in Figure 2. The increase of unit cell volume with increasing $\mathrm{Fe}$ content clearly indicates a solid solution of $\mathrm{Fe}$ in $\mathrm{ZnO}$ which is expected from the ionic radii. The radius of 4 -fold coordinated $\mathrm{Fe}^{2+}$ is $0.77 \AA$ compared to $0.74 \AA$ of $\mathrm{Zn}^{2+}$ (Table 6). Additionally, there is experimental evidence that only $\mathrm{Fe}^{2+}$ is substituting zinc in $\mathrm{ZnO}$ at conditions used in the present study: (i) Mössbauer spectroscopy of $\mathrm{Zn}_{0.89} \mathrm{Fe}_{0.11} \mathrm{O}$ produced by chemical vapour transport revealed predominantly $\mathrm{Fe}^{2+}$ [8]. (ii) Even little amounts of $\mathrm{Fe}^{3+}$ in $\mathrm{ZnO}$ produce typical inversion domains and related boundaries [14] which are readily detected in the electron microscope. However, none of such defects were observed in the $\left(\mathrm{Zn}_{1-y} \mathrm{Fe}_{y}\right) \mathrm{O}$ mixed crystals studied here. Also, the observed tendency of lattice parameter variation of $\left(\mathrm{Zn}_{1-y} \mathrm{Fe}_{y}\right) \mathrm{O}$ with $\mathrm{Fe}$ content is reported in the literature [8].

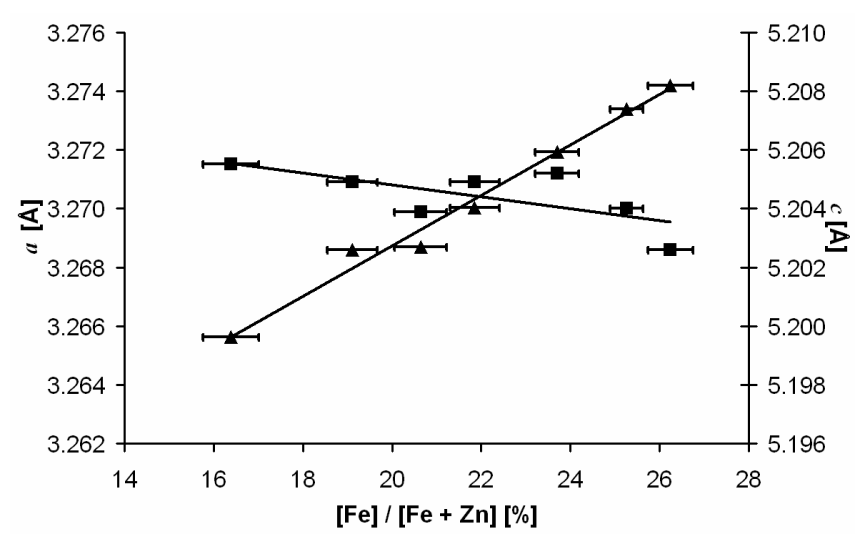

Figure 2. Lattice parameter $a$ (triangles) and $c$ (rectangles) of $\mathrm{Zn}_{1-y} \mathrm{Fe}_{y} \mathrm{O}$ plotted vs. Fe content. Error bars show standard deviation.

Wüstite Type $\mathrm{Fe}_{1-x-z} \mathrm{Zn}_{z} \mathrm{O}$
In order to study in detail the substitution of Fe with $\mathrm{Zn}^{2+}$ a series of mixed crystals $\mathrm{Fe}_{1-x-z} \mathrm{Zn}_{z} \mathrm{O}$ with $0.04<z<0.19$ was prepared at $1273 \mathrm{~K}$ for $72 \mathrm{~h}$. The starting materials and the resulting compositions of the products are listed in Table 1 , samples no. 8 to 18 . The standard deviation of the composition of wüstite products given in Table 1 is throughout less than $1 \%$ (see also Figure 3 ). The refinement results of the lattice parameter $a$ subject to the amount of $\mathrm{Zn}^{2+}$ ions built in the wüstite crystal are listed in Table 4 . To better visualise the tendency, in Figure 3 the lattice parameter $a$ is plotted over the composition. An unusual behaviour of the size of the unit cell is observed: while $a$ increases with $\mathrm{Zn}$ content up to ca. 13 at. \% of cations (regime I), $a$ remains virtually constant at higher $\mathrm{Zn}$ contents (regime II).

Table 4. Refined lattice parameter $a$ of $\mathrm{Fe}_{1-x-z} \mathrm{Zn}_{z} \mathrm{O}$ as function of composition (see Table 1).

\begin{tabular}{cccc}
\hline Sample no. & $a[\AA]$ & GOF / $\%$ & $R_{\mathrm{B}} / \%$ \\
\hline 8 & $4.3137(1)$ & 11.9 & 1.8 \\
9 & $4.3162(1)$ & 8.3 & 1.4 \\
10 & $4.3170(1)$ & 11.1 & 2.8 \\
11 & $4.3180(1)$ & 16.5 & 7.4 \\
12 & $4.3184(1)$ & 12.8 & 5.2 \\
13 & $4.3191(1)$ & 11.6 & 2.2 \\
14 & $4.3191(1)$ & 8.6 & 2.9 \\
15 & $4.3190(1)$ & 8.9 & 2.2 \\
16 & $4.3188(1)$ & 10.3 & 3.9 \\
17 & $4.3189(1)$ & 8.4 & 4.1 \\
18 & $4.3190(1)$ & 7.7 & 2.7 \\
\hline
\end{tabular}

To understand and discuss the increase of the lattice parameter $a$ in regime I the two possible sites for $\mathrm{Zn}^{2+}$ substitution, tetrahedral or octahedral, have to be considered. Tetrahedrally coordinated $\mathrm{Zn}^{2+}$ as interstitial in the sodium chloride structure of wüstite requires removal of four neighbouring $\mathrm{Fe}^{2+}$ ions, and substitution of other $\mathrm{Fe}^{2+}$ ions by $\mathrm{Fe}^{3+}$ because of charge balance. A single $\mathrm{Zn}^{2+}$ ion in tetrahedral site affords the substitution of $6 \mathrm{Fe}^{2+}$ ions in octahedral sites by $\mathrm{Fe}^{3+}$. The principle of occupying $\mathrm{Zn}^{2+}$ ions in tetrahedral sites is the same as for the defect clusters in wüstite, such as the prominent Koch-Cohen cluster with four $\mathrm{Fe}^{3+}$ ions in tetrahedral sites and 14 additional $\mathrm{Fe}^{3+}$ ions in octahedral sites. A structural equivalent cluster with four $\mathrm{Zn}^{2+}$ ions would even require $18 \mathrm{Fe}^{3+}$ ions in octahedral sites. On the other hand, substitution of $\mathrm{Fe}^{2+}$ by $\mathrm{Zn}^{2+}$ on octahedral sites does not cause structural and charge problems and may not affect the amount of $\mathrm{Fe}^{3+}$ in wüstite.

Hence, the amount of $\mathrm{Fe}^{3+}$ in wüstite with zinc solute is the appropriate quantity to provide information on the preferred sites of $\mathrm{Zn}^{2+}$. The ratio of $\mathrm{Fe}^{2+} / \mathrm{Fe}^{3+}$ was determined with Mössbauer spectroscopy in the sample no. 9 with composition $\mathrm{Fe}_{0.91} \mathrm{Zn}_{0.09} \mathrm{O}$. The resulting spectrum is shown in Figure 4. Its doublet structure consists of three doublets: doublets 1 and 2 are assigned to $\mathrm{Fe}^{2+}$, and doublet 3 is assigned to $\mathrm{Fe}^{3+}$. Small amounts $(5 \%)$ of metallic iron produce a weak sextet whose outer lines are out of the range of Figure 4. The interpretation of the Mössbauer spectrum is summarized in Table 5 . The analysis results in $93 \%$ of $\mathrm{Fe}^{2+}$ and in $6.5 \%$ of $\mathrm{Fe}^{3+}$ of the iron content in $\mathrm{Fe}_{0.91} \mathrm{Zn}_{0.09} \mathrm{O}$. The amount of $\mathrm{Fe}^{3+}$ is thus lower than in wüstite $\left(9 \% \mathrm{Fe}^{3+}\right)$ produced at similar conditions. As a consequence, the $\mathrm{Zn}^{2+}$ ions preferentially must occupy octahedral sites in the wüstite host crystal. 


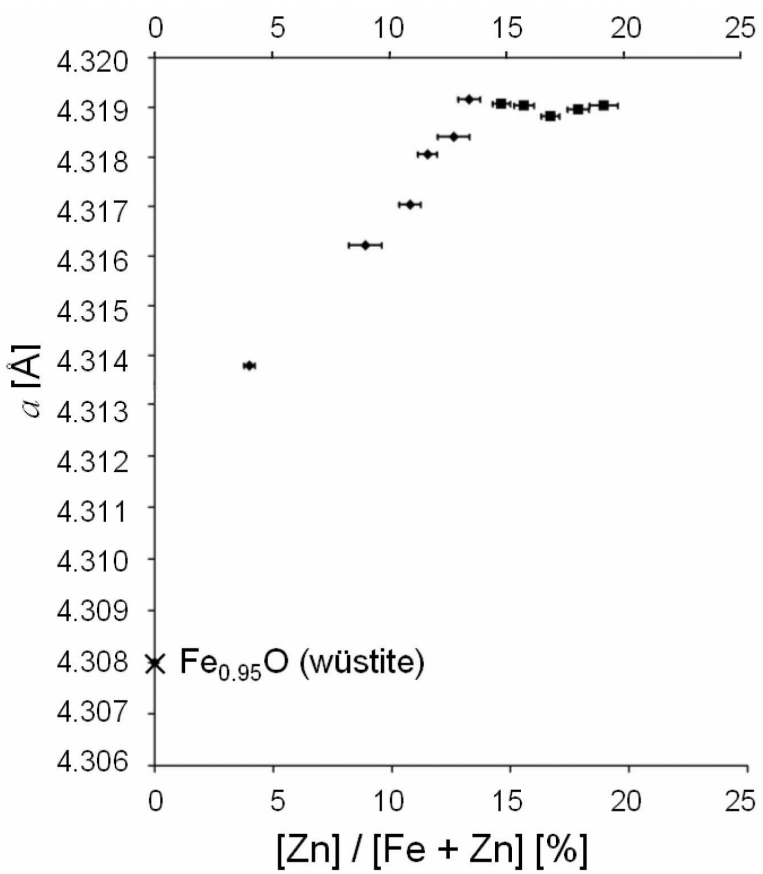

Figure 3. Lattice parameter $a$ of the wüstite type $\left(\mathrm{Fe}_{1-x-z} \mathrm{Zn}_{z} \mathrm{O}\right)$ as function of $\mathrm{Zn}$ content. Error bars show standard deviation.

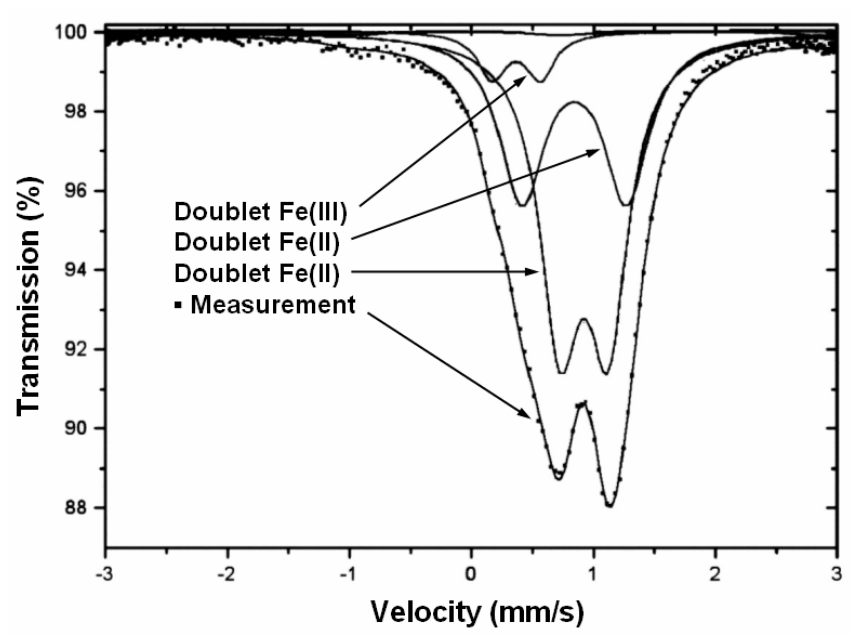

Figure 4. Mössbauer spectrum of sample $\mathrm{Fe}_{0.91} \mathrm{Zn}_{0.09} \mathrm{O}$ measured in the velocity range $\pm 3 \mathrm{~mm} / \mathrm{s}$.

Table 5. Results of Mössbauer Spectra of Sample $\left(\mathrm{Fe}_{0.91} \mathrm{Zn}_{0.09}\right) \mathrm{O}$.

\begin{tabular}{lllll}
\hline Site & $\begin{array}{l}\text { IS } \\
{[\mathrm{mm} / \mathrm{s}]^{[\mathrm{a}]}}\end{array}$ & $\begin{array}{l}\mathrm{QS} \\
\left.[\mathrm{mm} / \mathrm{s}]^{[\mathrm{b}]}\right]\end{array}$ & $\begin{array}{l}\text { Relative } \\
\text { Area }(\%) \\
\text { Total Iron }\end{array}$ & $\begin{array}{l}\text { Relative } \\
\text { Area }(\%) \\
\text { Oxide only }\end{array}$ \\
\hline $\mathrm{Fe}^{2+}{ }^{2+}$ & $0.95(1)$ & $0.85(3)$ & $34(6)$ & $36(6)$ \\
$\mathrm{Fe}^{2+}{ }^{\text {oct }}$ & $1.03(1)$ & $0.39(2)$ & $54(6)$ & $57(6)$ \\
$\mathrm{Fe}^{3+}$ & $0.37(3)$ & $0.40(5)$ & $6.1(5)$ & $6.5(5)$ \\
$\mathrm{Fe}^{0}$ & 0.0 & -- & $5(2)$ & -- \\
\hline
\end{tabular}

[a] isomeric shift, [b] quadrupolar splitting
At first sight, substitution of $\mathrm{Fe}^{2+}$ by $\mathrm{Zn}^{2+}$ with smaller ionic radius should yield a smaller unit cell volume (see Table 6). However, the lattice parameter measured clearly shows the opposite in regime I for small zinc contents. Thus the increase of cell volume has to be attributed to the decrease of $\mathrm{Fe}^{3+}$ in the mixed crystals $\mathrm{Fe}_{1-x-z} \mathrm{Zn}_{z} \mathrm{O}$. The same tendency of lattice parameter increase is observed in the system $\mathrm{Fe}_{1-\mathrm{x}} \mathrm{O}-\mathrm{MgO}$ which exhibits complete solid solubility of the crystals $\mathrm{Fe}_{1-x-z} \mathrm{Mg}_{z} \mathrm{O}[15,16] . \mathrm{Fe}_{1-x-z} \mathrm{Mg}_{z} \mathrm{O}$ shows a pronounced deviation from Vegard's law, i.e. the cell parameter is clearly exceeding Vegard's line $\mathrm{Fe}_{1-x} \mathrm{O}-\mathrm{MgO}$ in the $\mathrm{Fe}$ rich region [16]. Additionally, Mössbauer spectroscopy revealed a strong decrease of the relative amount of $\mathrm{Fe}^{3+}$ in particular at low solute content of $\mathrm{MgO}$ content. In the system $\mathrm{Fe}_{1-\mathrm{x}} \mathrm{O}-\mathrm{MnO}$ this observations is quite similar: the amount of $\mathrm{Fe}^{3+}$ decreases by substituting $\mathrm{Fe}^{2+}$ with $\mathrm{Mn}^{2+}$ [17]. In the system $\mathrm{Fe}_{1-\mathrm{x}} \mathrm{O}-\mathrm{ZnO}$ a Vegard's line can be drawn if the cell parameter $a=4.28 \AA$ for $\mathrm{ZnO}$ is used which is obtained from high pressure $\mathrm{ZnO}$ with $\mathrm{NaCl}$ structure [18]. Hence, we observe a drastic deviation from Vegard's law in the mixed crystals $\mathrm{Fe}_{1-x-z} \mathrm{Zn}_{z} \mathrm{O}$.

In wüstite with additions of oxides with two-valent cations considered here, the following may be summarized: substitution of $\mathrm{Fe}^{2+}$ by $\mathrm{Mg}^{2+}$ and $\mathrm{Zn}^{2+}$ ions on octahedral sites in the wüstite lattice result in an increase of the lattice constant larger than predicted by Vegard's law. This is a direct consequence of the removal of $\mathrm{Fe}^{3+}$ on octahedral and tetrahedral sites and implies a diminished amount of defect clusters compared to wüstite.

Table 6. Ionic radii of $\mathrm{Fe}, \mathrm{Zn}, \mathrm{Mn}$ and $\mathrm{Mg}$ in fourfold and sixfold coordination [19].

\begin{tabular}{llllll}
\hline Coordination & $\mathrm{Fe}^{2+}$ & $\mathrm{Fe}^{3+}$ & $\mathrm{Zn}^{2+}$ & $\mathrm{Mg}^{2+}$ & $\mathrm{Mn}^{2+}$ \\
& $r[\AA]$ & $r[\AA]$ & $r[\AA]$ & $r[\AA]$ & $r[\AA]$ \\
\hline tetrahedral & 0.77 & 0.63 & 0.74 & 0.71 & 0.80 \\
octahedral & 0.92 & 0.785 & 0.88 & 0.86 & 0.97
\end{tabular}

\section{$\mathrm{Fe}_{1-x-z} \mathrm{Zn}_{z} \mathrm{O}$ with High Zinc Content}

As shown in Figure 3, the lattice parameter of the mixed crystals $\mathrm{Fe}_{1-x-z} \mathrm{Zn}_{z} \mathrm{O}$ with high concentrations of $\mathrm{Zn}^{2+}(0.13<$ $z<0.18$ ) remains constant. Obviously, in this regime II of higher zinc content the increase of lattice parameter due to removal of $\mathrm{Fe}^{3+}$ and its decrease by occupying $\mathrm{Zn}^{2+}$ cations in octahedral sites balances.

Even higher contents of $\mathrm{Zn}^{2+}$ are realised in crystals prepared at temperatures above $1300 \mathrm{~K}$ at the solubility limit (see Table 2). The corresponding lattice parameters are listed in Table 7 and are visualised and plotted versus the zinc content (Figure 5). As expected from the smaller ionic radius of $\mathrm{Zn}^{2+}$ compared to $\mathrm{Fe}^{2+}$ the lattice parameter decreases with increasing zinc content. For such high zinc content the impact of the occupation of small $\mathrm{Zn}^{2+}$ ions exceeds the effect of removal of $\mathrm{Fe}^{3+}$ ions.

Table 7. Lattice Parameter of cubic $\left(\mathrm{Fe}_{1-x-2} \mathrm{Zn}_{7}\right) \mathrm{O}$ with high $\mathrm{Zn}$ content (see Table 2).

\begin{tabular}{cccc}
\hline $\begin{array}{c}\text { Sample } \\
\text { no. }\end{array}$ & $a[\AA]$ & GOF [\%] & $R_{\mathrm{B}}[\%]$ \\
\hline 1 & $4.3200(1)$ & 7.9 & 1.05
\end{tabular}




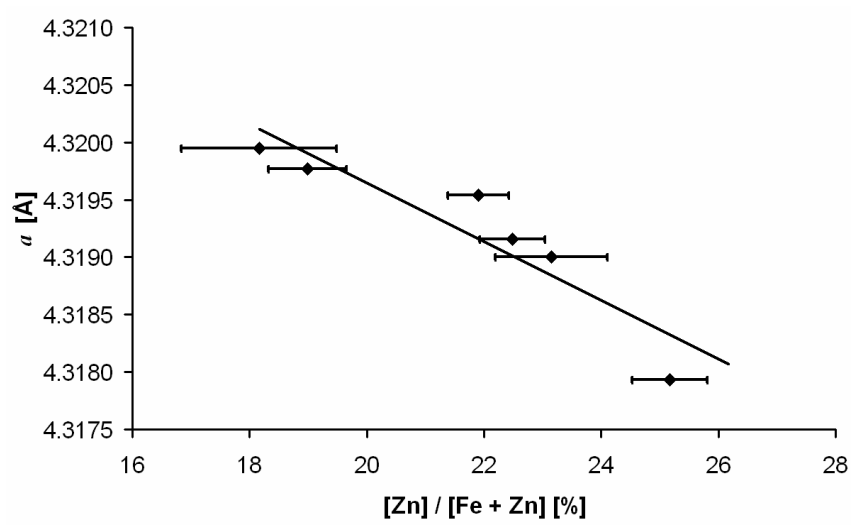

Figure 5. Lattice parameter $a$ of the wüstite phase $\left(\mathrm{Fe}_{1-x-z} \mathrm{Zn}_{z}\right) \mathrm{O}$ vs. $\mathrm{Zn}$ content. Error bars show standard deviation.

\section{Conclusions}

In our systematic study the maximum solid solubilities of $\mathrm{Fe}$ and $\mathrm{Zn}$ in the phases $\mathrm{Zn}_{1-y} \mathrm{Fe}_{y} \mathrm{O}$ and $\mathrm{Fe}_{1-x-z} \mathrm{Zn}_{z} \mathrm{O}$, respectively, were found to be substantial, and $y$ and $z$ exceed 0.25 at $1473 \mathrm{~K}$. With increasing content of $\mathrm{Fe}^{2+}$ the $a$ axis of the phase with wurtzite structure increases while the c axis slightly decreases. Thus, the $c / a$ ratios of the mixed crystals are even further away from the ideal value.

Surprisingly, small amounts of $\mathrm{Zn}^{2+}$ ions at octahedral sites result in an increase of the lattice parameter in the series of mixed crystals $\mathrm{Fe}_{1-x-z} \mathrm{Zn}_{z} \mathrm{O}$. This increase is the result of substituting $\mathrm{Fe}^{3+}$ at octahedral sites by $\mathrm{Zn}^{2+}$, which - because of charge balance arguments -leads to removal of $\mathrm{Fe}^{3+}$ at tetrahedral sites. Finally, the amount of defect clusters, compared to wüstite, is diminished. Such behaviour is also observed in the systems $\mathrm{Fe}_{1-\mathrm{x}} \mathrm{O}-\mathrm{MgO}$ and $\mathrm{Fe}_{1-\mathrm{x}} \mathrm{O}$ $\mathrm{MnO}$ with a smaller ionic radius and a larger ionic radius of $\mathrm{M}^{2+}$ ions than $\mathrm{Fe}^{2+}$, respectively. These observations lead us to the conclusion that dilution of $\mathrm{Fe}^{2+}$ by any appropriate addition of two-valent ions to wüstite reduces the necessity of formation of $\mathrm{Fe}^{3+}$ and hence of defect cluster creation. At higher $\mathrm{ZnO}$ contents $\mathrm{Fe}^{2+}$ is substituted by smaller $\mathrm{Zn}^{2+}$ ions at octahedral sites thus balancing or even reversing the effect of $\mathrm{Fe}^{3+}$ substitution.

\section{Acknowledgments}

We would like to acknowledge Dr. Wilfried Assenmacher and Dr. Klemens Kelm for their help in experimental work and for fruitful discussions.

[1] Ü. Özgür, J. Appl. Phys. 2005, 98, 041301-1-103.

[2] a) R.M. Hazen, R. Jeanloz, Rev. Geophys. Space Phys. 1984, 22, 37-46; b) L. Minervini, R.W. Grimes, J. Phys. Chem. Solids 1999, 60, 235-245; c) W. Schweika, A. Hoser, M.
Martin, A.E. Carlsson, Phys. Rev. B 1995, 51, 15771; d) R.W. Grimes, A.B. Anderson, A.H. Heuer J. Am. Chem. Soc. 1986, 69, 619-623.

[3] F. Koch, J.B. Cohen, Acta. Cryst. 1969, B 25, 275-287.

[4] P.K. Foster, A. J. E. Welch, Trans. Faraday Soc. 1956, 52, 1626-1635.

[5] a) S.A. Degterov, E. Jak, P.C. Hayes, A.D. Pelton, Metall. Mat. Trans. B 2001, 32B, 643-657; b) R. Hansson, P.C. Hayes, E. Jak, Metall. Mat. Trans. B 2005, 36B, 179-185; c) R. Hansson, P.C. Hayes, E. Jak, Scand. J. Metall. 2004, 33, 294-304; d) R. Hansson, P.C. Hayes, E. Jak, Trans. Inst. Min. Metall. C 2005, 114, 141-146.

[6] E. Jak, B. Zhao, P.C. Hayes, Metall. Mat. Trans. B 2000, $31 B, 1195-1201$.

[7] J.M. Claude, M. Zanne, C. Gleitzer, J. Aubry, Mem. Scient. Rev. Metall. 1977, 229-236.

[8] S. Locmelis, M. Binnewies, Z. Anorg. Allg. Chem. 1999, 625, 1573-1577.

[9] T. Degen, Diffrakt 97, V0.99, Programm zur Auswertung von Pulverdaten 1998.

[10] P.E. Werner, L. Eriksson, M. Westdahl, J. Appl. Cryst. 1985, $18,267$.

[11] R. J. Hill, C.J. Howard, LHPM, A Computer Program for Rietveld Analysis of Fixed-Wavelenght X-Ray and Neutron Diffraction Patterns. Australian Atomic Energy Comission (now Ansto) Report No. M112. Lucas Height Research Laboratories, New South Wales, Australia. 1986.

[12] K. Lagarec, D.G. Rancourt, Recoil - Mössbauer Spectral Analysis Software for Windows, version 1.02. 1998, Department of Physics, University of Ottawa, Ottawa.

[13] E. Fromm, E. Gebhardt in Gase und Kohlenstoff in Metallen, Springer-Verlag, Berlin, 1976, vol. 1, p. 601.

[14] O. Köster-Scherger, H. Schmid, N. Vanderschaeghe, F. Wolf, W. Mader, J. Am. Ceram. Soc. 2007, 90, 3984-3991.

[15] a) I. Srečec, A. Ender, E. Woermann, W. Gans, E. Jacobsson, G. Eriksson, E. Rosén, Phys. Chem. Min. 1987, 14, 492-498; b) In-Ho Jung, S.A. Decterov, A.D. Pelton, J. Phys. Chem. Sol. 2004, 65, 1683-1695.

[16] H.St.C. O^Neil, M.I. Pownceby, C.A. McCammon, Contr. Min. Petr. 2003, 146, 308-325.

[17] T. Sano, M. Tsuji, Y. Tamaura, Solid State Ionics, 1997, 104, 311-317.

[18] C.H. Bates, W.B. White, R. Roy, Science, 1962, 137, 993.

[19] R.D. Shannon, C.T. Prewitt, Acta Chryst. 1969, B25, 925946.

Received: ((will be filled in by the editorial staff)) Published online: ((will be filled in by the editorial staff)) 


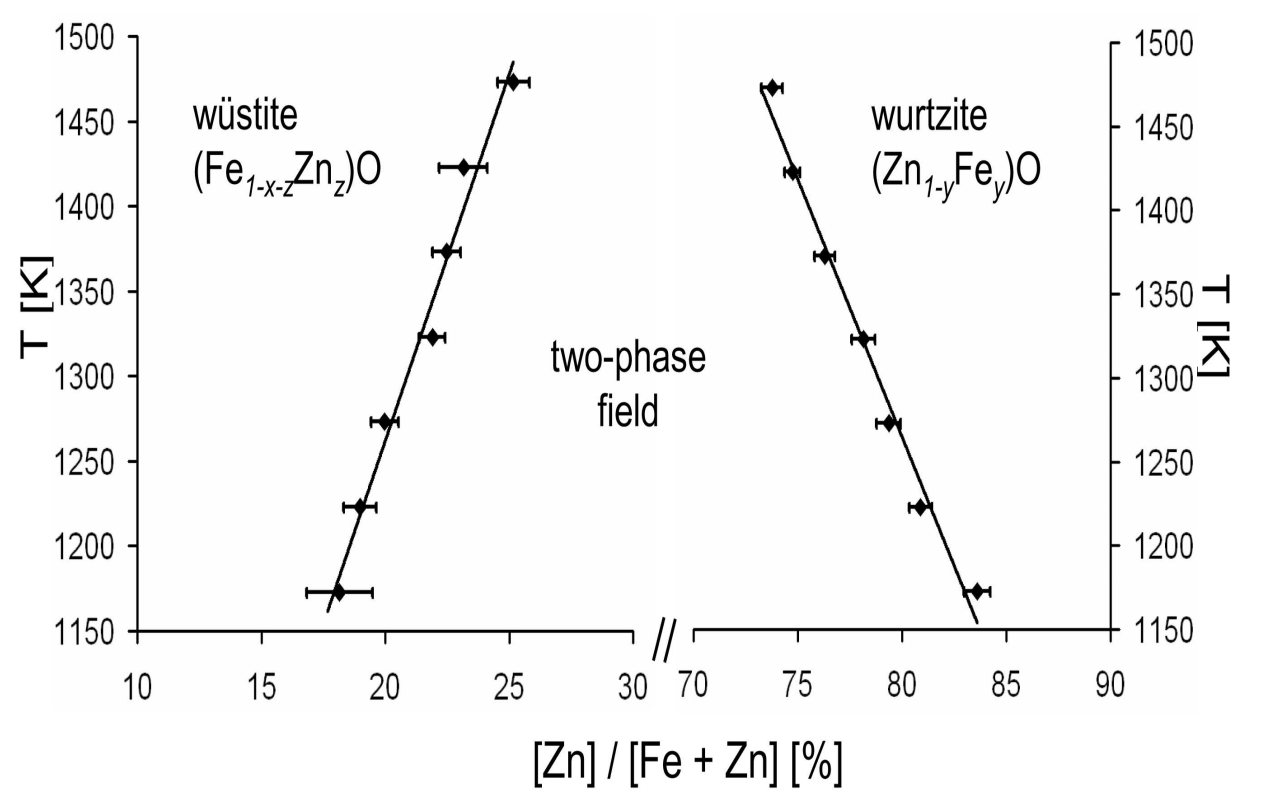

$244 \times 160 \mathrm{~mm}(300 \times 300$ DPI $)$ 


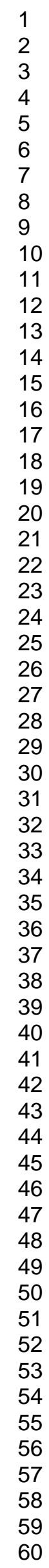

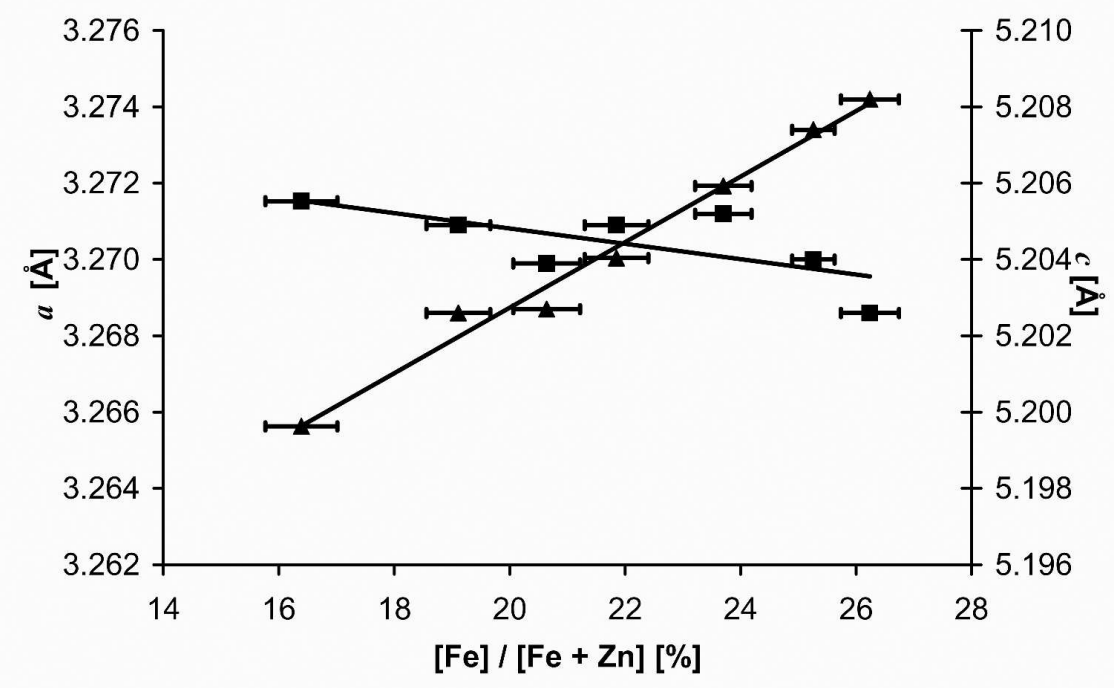

$297 \times 209 \mathrm{~mm}(300 \times 300 \mathrm{DPI})$ 


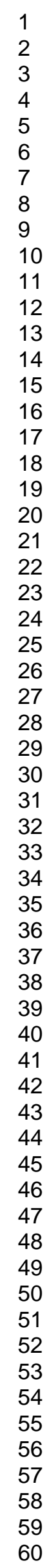

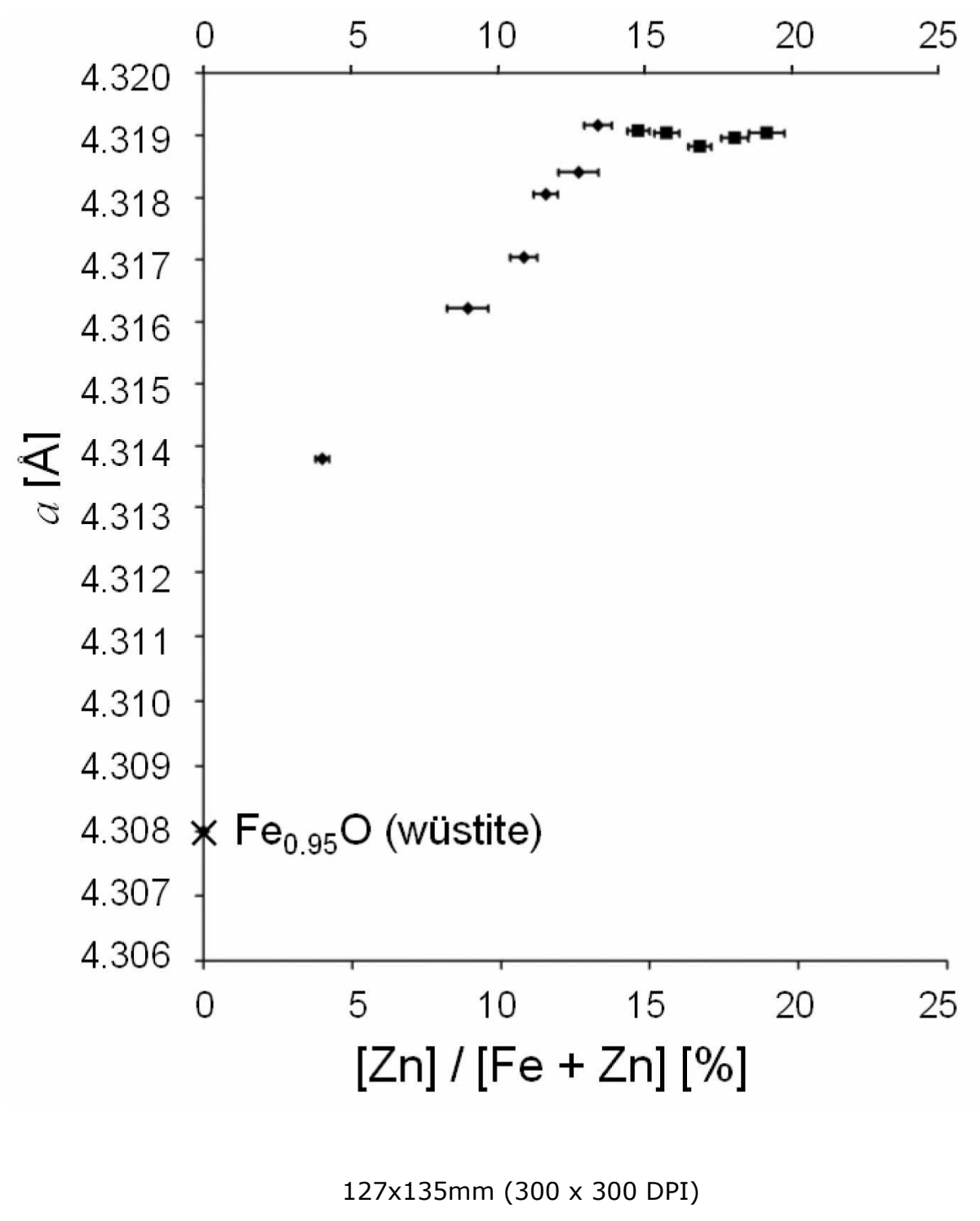




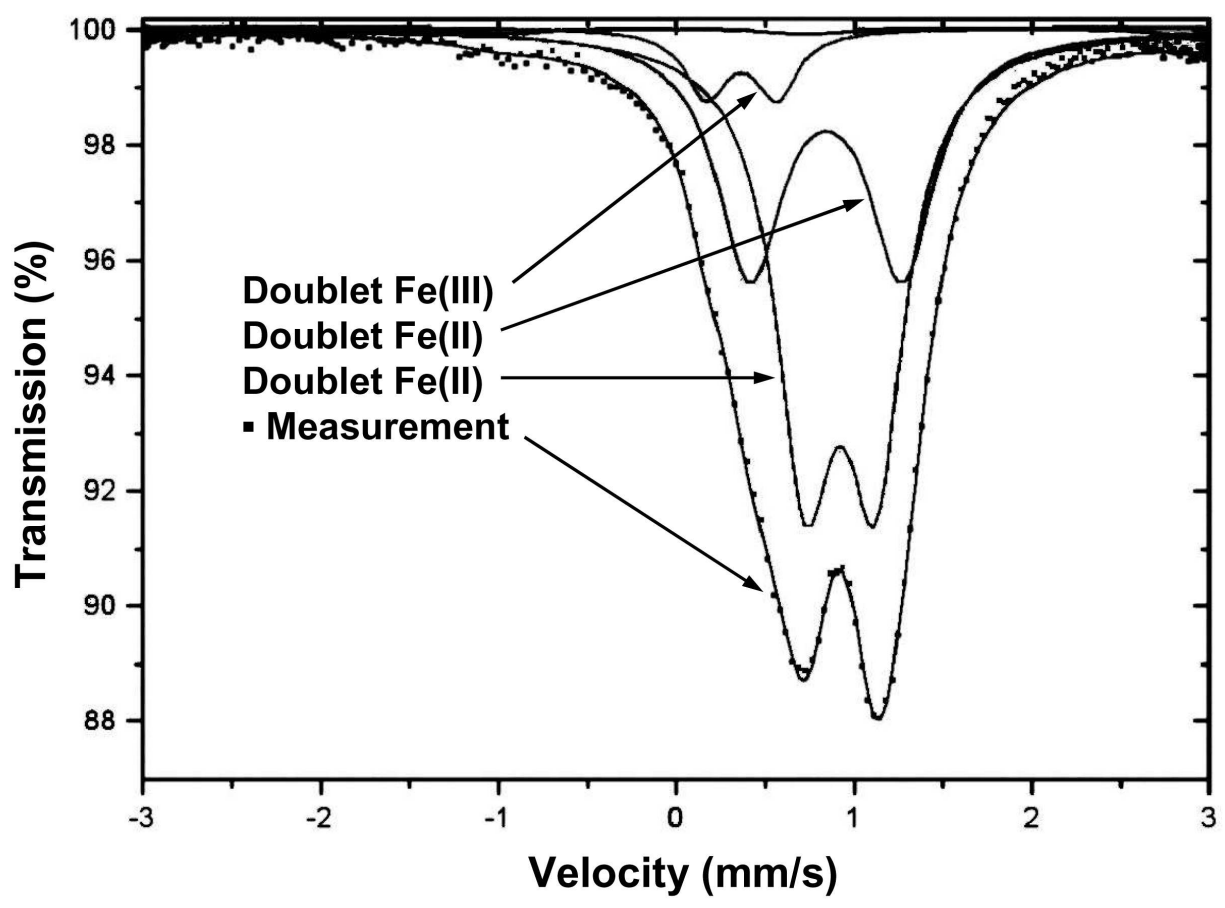

$218 \times 160 \mathrm{~mm}(300 \times 300$ DPI $)$ 
1

2

3

4

5

6

7

8

9

10

11

12

13

14

15

16

17

18

19

20

21

22

23

24

25

26

27

28

29

30

31

32

33

34

35

36

37

38

39

40

41

42

43

44

45

46

47

48

49

50

51

52

53

54

55

56

57

58

59

60

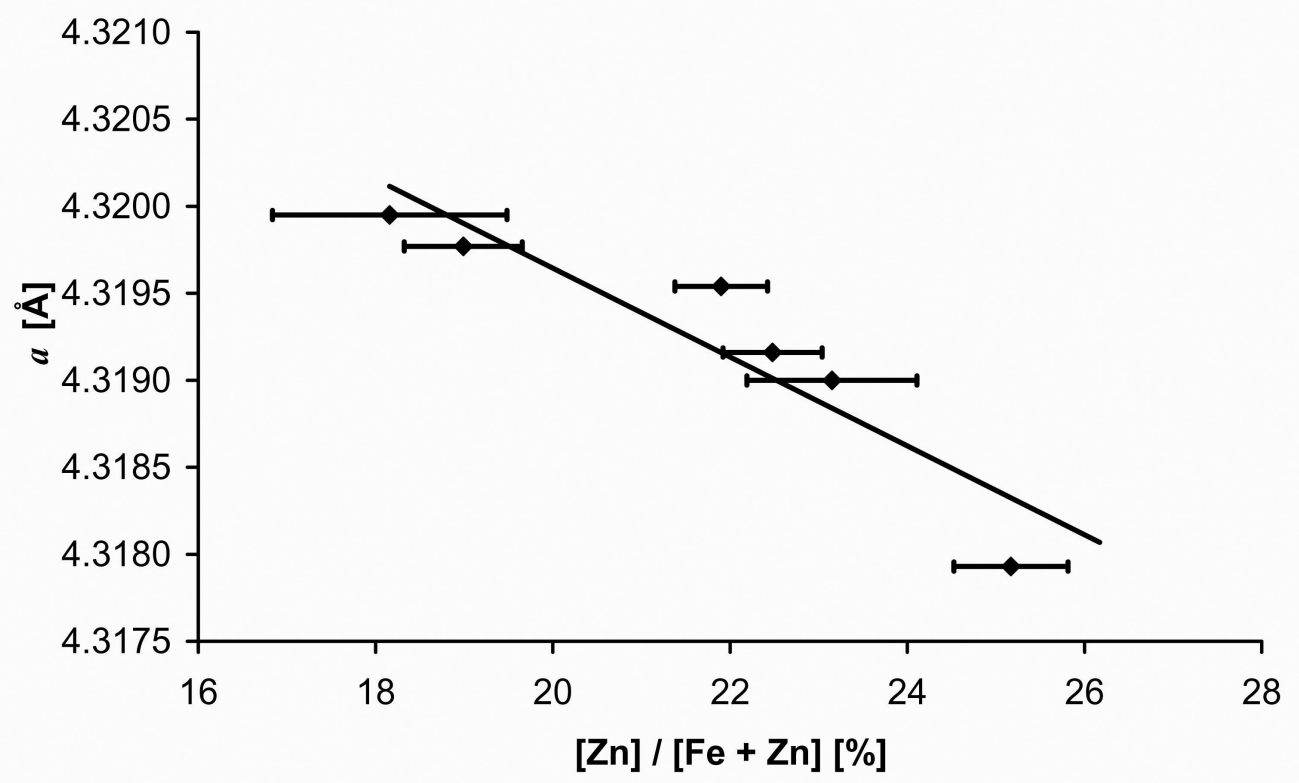

$256 \times 160 \mathrm{~mm}(300 \times 300$ DPI $)$ 